\title{
Formas híbridas de narrativa: reflexiones sobre el cómic autobiográfico
}

\author{
Narrative Hybrid Forms: reflections on \\ autobiographic comic
}

\author{
Susana ARROYo REDONDO \\ Universidad de Alcalá \\ susana.arroyo@uah.es
}

Recibido: 08/02/2010

Aceptado: 17/01/2011

\section{Resumen}

Desde los años setenta, el cómic ha ido abandonando su posición subcultural para convertirse en una manifestación artística reconocida, idónea para la expresión autobiográfica o la denuncia social. Por ello, este artículo se interesará por su historia, así como por las características estilísticas, estructurales y temáticas propias del cómic autobiográfico. El análisis mostrará cómo el auge del cómic confesional se relaciona con el progresivo interés que la confesión y lo autobiográfico despierta en la cultura posmoderna.

Palabras clave: cómic, novela gráfica, autobiografía, narración.

\begin{abstract}
Since the seventies, comics have abandoned their old marginal position to become a highly praised form of art, suitable for autobiographical or historical recounts. Therefore, in this paper we analyse autobiographical comics' history, and their main stylistic, structural and thematic features. This study will show how the rise of confessional comics in postmodern culture is linked to a growing interest in autobiographical expressions.
\end{abstract}

Keywords: Comic Book, Graphic Novel, Autobiography, Narrative. 


\section{Sumario}

1. Introducción

2. El lenguaje propio del cómic

3. Acuerdos formales y pragmáticos: ¿cómo reconocer el cómic autobiográfico?

4. Alcance cultural del cómic autobiográfico

5. Conclusiones

\section{Introducción}

A lo largo de su breve historia, el cómic ha librado una dura batalla por ganarse el reconocimiento público como un arte con valores estéticos propios. Desde sus inicios en la prensa periódica decimonónica ${ }^{1}$ hasta su legitimación artística durante el último cuarto del siglo XX, esta forma híbrida ha pasado más de una centuria refugiada en el mundo del humorismo, en el mercado de las producciones infantiles y, más tarde, en el ideario expresivo de los movimientos subculturales juveniles. Sólo a partir de la década de los setenta logró hacerse un hueco en las estanterías de las grandes librerías, obtener premios, disfrutar de festivales propios como el de Angoulême o el Comic Con, y llegar a acaparar hasta el tres por ciento de la producción editorial en España.

Los procesos de maduración intrínseca que han contribuido al progresivo acercamiento del cómic a un público adulto y a un estatus artístico deben mucho al perfeccionamiento de las técnicas narrativas y gráficas del medio: el uso de estilos cercanos al expresionismo, la mejora de los modos para captar el movimiento, el juego con la disposición de las viñetas y su ordenación cronológica, el desarrollo de nuevas relaciones posibles entre texto y viñetas, etc. También ha resultado fundamental la modificación en los procesos de distribución del cómic, pues la sencilla tira cómica de las publicaciones periódicas ha ido cediendo terreno a nuevos formatos como los comic books (cuadernos seriales) y las llamadas «novelas gráficas» (volúmenes completos publicados en un tomo unitario) ${ }^{2}$. La excelente acogida de Blankets

\footnotetext{
${ }^{1}$ Existe una notable polémica en torno al nacimiento del cómic. Generalmente se hace remontar sus raíces a los murales con escenas seriales egipcios y precolombinos, o también al desarrollo de la imprenta y los historietistas cómicos del XVIII (McCloud, S., Entender el cómic: el arte invisible, Bilbao, Astiberri, 1993, pp. 19-20). Aquí, sin negar la influencia de estos hitos, se situará el nacimiento cómic a mediados del siglo XIX, en el desarrollo de la prensa como un medio de comunicación masivo adaptado a una sociedad industrial (sobre esta postura, véase Gubern R., El lenguaje de los cómics, Barcelona, Península, 1972, pp. 13-15).

$2 \mathrm{Al}$ cómic con aspiraciones artísticas se le comenzó a llamar en los sesenta «novela gráfica» (Weiner, S. y Couch, Ch., Faster than a speeding bullet: the rise of the graphic novel, Nueva York, NBM, 2003, pp. 17-20), un nombre muy popular hoy en día, aunque en este artículo se usará con preferencia el término genérico de «cómic», pues no parece existir evidencia de que ambos vocablos designen hoy por
} 
(2003), un cómic autobiográfico de casi seiscientas páginas sobre la juventud de Craig Thompson, ofrece un buen ejemplo del cambio en el trato que la industria editorial y el mercado dispensa al cómic, pues hasta entonces era raro (por lo menos en Occidente) encontrar libros tan extensos publicados sin serialización previa ${ }^{3}$.

Pero en la maduración del cómic también ha intervenido un componente temático, relacionado con el notable acercamiento de esta forma narrativa a temas más complejos de los de su repertorio primitivo. Sin haber abandonado nunca sus tradicionales motivos fantásticos, heroicos y de ciencia-ficción -hoy plenamente vigentes en el mercado-, no es raro encontrar cómics súper ventas que plantean problemas existenciales, reflexiones sobre la condición humana o el devenir histórico; asuntos antes sólo reservados a la literatura, la pintura y otras artes canónicas. De hecho, no es sólo que el cómic haya asumido temas más oscuros y dramáticos (violencia, sexo, maltrato, enfermedad...) sino que ha enfocado directamente a la realidad asumiendo géneros de «no ficción» como la crónica periodística o la auto/biografía. Con esto no se pretende insinuar aquí, por supuesto, que el cómic (o la literatura o el cine) de ficción no permita reflexiones sobre el mundo o sobre la condición humana o que de la lectura de una historia imaginaria no se puedan extraer conclusiones para la vida real; se trata de que los géneros de no ficción (la crónica, el retrato, el documental) exigen una adhesión estricta a la realidad y una sinceridad evidente 4 . En este sentido, la incursión del cómic en temas no ficticios a partir los años setenta ha resultado fundamental para restaurar poco a poco su imagen ante los ojos del público y de la crítica. De ser una forma menor de entretenimiento, el cómic ha pasado a ser considerado un medio con capacidad expresiva suficiente como para abordar directamente la realidad.

Por este motivo, en las páginas que siguen se analizará qué papel han ejercido el testimonio personal y la confesión autobiográfica a la hora de situar al cómic en el canon artístico contemporáneo. Se buscará mostrar cómo el advenimiento del cómic a la lista de artes canónicas y su reconocimiento masivo por parte del público general no es desde luego una casualidad o un mero producto de marketing, sino

hoy realidades separadas más allá de ciertos intereses editoriales. Es evidente que en los sesenta, cuando el término «novela gráfica» comenzó a usarse, y en los setenta, cuando Will Eisner lo popularizó, esta denominación pretendía dignificar un medio que empezaba a apostar por obras de temas más complejos que los superhéroes y los vaqueros, con un estilo de autor reconocible. Pero hoy en día, cuando ven la luz tantos cómics en formatos tan variados, el nombre apenas alude ya a ciertas constantes del formato de publicación: habitualmente un volumen serial firmado por un solo autor.

3 Curiosamente, un cauce de futuro para el cómic se desarrolla volviendo al formato de tiras seriales, aunque ahora en Internet. Se trata del webcómic, una fusión de blog personal y tiras actualizadas regularmente que permite seguir con inmediatez la vida del autor (respondiendo así a la actual demanda de un acceso cada vez más rápido a la información) y participar con comentarios o sugerencias en el desarrollo de las historias.

4 Sobre esta perspectiva humanista que reconoce el poder de la ficción para influir sobre el mundo a pesar de no aludir a él directamente, véase Lamarque P. y Olsen S. H., Truth, Fiction, and Literature: a philosophical perspective, Oxford, Oxford University Press, 1996. 
un proceso coherente con la evolución general de la cultura posmoderna. El desplazamiento de la cultura occidental hacia nuevos valores estéticos más relajados, donde priman menos la adscripción al estilo y a la tradición que la originalidad y la hibridación de formas, se encuentra en la raíz de la experimentación llevada a cabo por guionistas y dibujantes de cómics a partir de los sesenta. Y este mismo proceso también ayuda a explicar la positiva recepción del público ante estas producciones. Además, el tratamiento privilegiado que desde los años sesenta han dispensado la literatura, el cine y todas las artes plásticas a la expresión de la intimidad está obviamente relacionado con un progresivo cambio de sensibilidad en artistas y público. Por ello, el creciente empleo del formato cómic para tratar temas íntimos, memorialísticos o históricos desde una óptica personal ha contribuido en buena medida a mejorar la consideración del público hacia este arte. En este sentido, el estudio de la evolución estética y social del cómic -sobre todo el autobiográfico- servirá para ejemplificar desde un punto de vista novedoso el cambio en la percepción pública sobre lo artístico; es decir, qué nuevas exigencias estéticas y semánticas deben satisfacer los objetos culturales para entrar a formar parte del canon artístico occidental.

\section{El lenguaje propio del cómic}

Por más que el cómic pueda ser considerado hoy en día un arte popular y editorialmente exitoso, sus planteamientos teóricos resultan aún bastante desconocidos. Por ello, antes de continuar, resulta imprescindible ofrecer algunas definiciones sobre conceptos capitales para este estudio: cómo se define un cómic, qué aspectos separan los cómics ficticios y no ficticios, y qué caracteriza al cómic autobiográfico.

Respecto a qué es un cómic, Will Eisner aportó una definición hoy unánimemente aceptada: «arte secuencial» ${ }^{5}$. Es decir, el cómic se definiría como una serie de dos o más imágenes dispuestas en secuencia de modo que el lector pueda realizar el acto de «clausura», que consiste en rellenar el hueco que va de una secuencia estática a otra para componer así un relato. Las imágenes estáticas y sincopadas que componen los cómics ofrecen un vacío entre ellas, pero nuestra capacidad psicológica para la clausura completa esos huecos de modo significativo. Partiendo de estas ideas, el dibujante Scott McCloud ofreció en Entender el cómic una definición más completa: «Ilustraciones yuxtapuestas y otras imágenes en secuencia deliberada, con el propósito de transmitir información y obtener una respuesta estética del lector»6. Esta capacidad se muestra por ejemplo en el movimiento subjetivo que el lector capta entre imágenes estáticas como las siguientes ${ }^{7}$ :

\footnotetext{
5 Eisner W., El cómic y el arte secuencial, Barcelona, Norma, 1998.

6 McCloud 2007, op. cit. (nota 1), p. 17.

7 Spiegelman, A., Maus: Relato de un superviviente, Madrid, Planeta de Agostini, 2001, p. 65.
} 


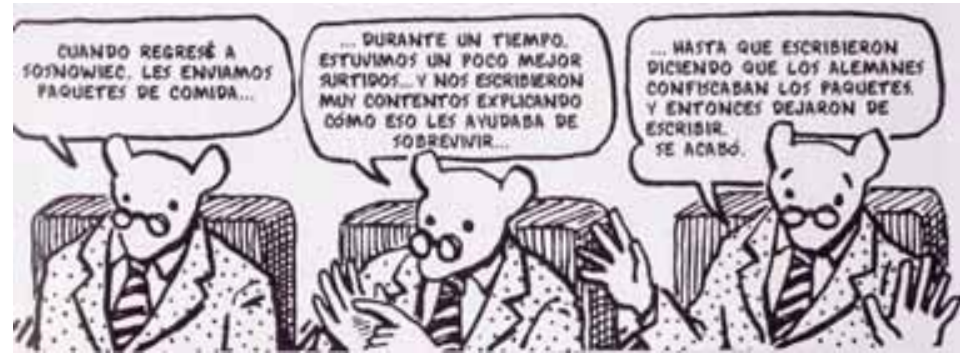

Este componente «secuencial» del cómic implica, por supuesto, la disposición cronológica de los eventos relatados. Es decir, que el cómic se construye sobre la misma noción de temporalidad que el cine y la literatura, las otras artes narrativas. Eso sí, para que la secuencialidad del cómic tenga éxito y se componga un relato, es necesario que el lector lleve a cabo la clausura de las viñetas. Esta clausura distingue al cómic de otras artes visuales, pues se trata de un proceso que no se realiza de forma automática (como en el cine) sino que el autor debe disponer las imágenes de forma que el lector, a través de una cooperación activa, pueda unirlas de una forma significativa. Cuanto más inconexas sean esas viñetas entre sí, o cuanto más complejo el dibujo o texto de cada viñeta, más deberá colaborar el lector en su descodificación, y el resultado será más representativo o artístico y menos lineal o narrativo. Así, por ejemplo, el cómic tradicional de superhéroes o aventuras (y el manga), que busca transmitir un mensaje claro y rotundo, recurre de forma general a un dibujo sencillo con transiciones evidentes, pero el cómic underground y sus derivados (como la llamada novela gráfica) han practicado transiciones más complejas que potencian la cooperación lectora.

Dentro del cómic, como dentro de todo arte narrativo, se pueden distinguir producciones de naturaleza ficticia (de tema imaginario, que relatan historias inventadas) y no ficticia (testimonios sobre la realidad y comentarios sobre el mundo). En el ámbito de la literatura, la no ficción corresponde al ensayo, la Historia o la biografía, y en el del cine al documental. Por lo que respecta al cómic, hay cada vez más ejemplos de guionistas dedicados a ofrecer su personal punto de vista desde este medio, ya sea en autobiografías y testimonios familiares, o en ensayos y crónicas periodísticas. Por supuesto, la separación entre la ficción y la no ficción no responde a premisas cerradas y bien delimitadas, sino a criterios con un componente de variabilidad sociocultural (la mitología y las vidas de santos conforman ejemplos clásicos de cómo la noción de «ficticio» puede variar con el tiempo). Sin embargo, en general, los géneros y marcos contextuales garantizan que los lectores puedan discernir sin problema que una crónica periodística publicada en un periódico debe entenderse como un relato sobre la realidad mientras que un cuento es una narración imaginaria. En todo caso, algunos géneros sí se sitúan en un límite más confuso, como por ejemplo la autobiografía, que a causa de su subjetividad se mueve en el filo entre ambas instancias. Dado su carácter de crónica individual y su afán estético a la vez que historiográfico, la confesión autobiográfica se enfrenta, sea en for- 
mato textual o historietístico, a un nivel fuerte de escepticismo por parte del público. Esto se debe a que el autor no suele tener otra prueba de su experiencia más allá de su propio testimonio, y también a la necesaria selección y manipulación que implica la disposición artística de los recuerdos.

Por lo tanto, el objetivo aquí consistirá primero en describir el funcionamiento de los mecanismos por los que un cómic se inscribe en la narración autobiográfica no ficticia, y segundo, investigar cómo la narrativa híbrida del cómic permite construir una imagen autobiográfica propia, irreductible a lo meramente literario o pictórico. Respecto al primer punto, en las siguientes páginas se reflexionará sobre cómo este tipo de cómic logra establecer la autenticidad de su historia gracias a recursos como la presencia del nombre del autor dentro del texto, la intervención del narrador, el estilo del dibujo, la narración en primera persona, los elementos paratextuales (título, subtítulo, portada...), etc. Respecto al segundo objetivo, se investigará cómo el componente visual del cómic le otorga, frente a la literatura, una inusitada potencia de exhibición personal. Pues a la descripción convencional de la vida y el pensamiento del autor se añade además su autorretrato, y esta representación corporal, ya sea realista, estilizada o simbólica (como el ratón mediante el que se retrata Spiegelman o el pájaro para Trondheim) ofrece una visión directa de la imagen que de sí mismo posee el autor, incluyendo sus complejos físicos y sus distorsiones personales ${ }^{8}$.

\section{Acuerdos formales y pragmáticos: ¿cómo reconocer el cómic autobiográfico?}

La inclinación autobiográfica y el punto de vista subjetivo no aparecen en el cómic hasta la década de los setenta del siglo pasado, justo en el momento en que el cómic en general comienza a explorar sus posibilidades expresivas. Jean-Pierre Mercier9 menciona Binky Brown meets The Holy Virgin Mary (1972) como el primer cómic autobiográfico, una historia underground que narra de forma explícita las obsesiones derivadas de la dura infancia de la autora, Justin Green. Este tono

\footnotetext{
${ }^{8}$ En el mundo del cómic, guionista y dibujante tienden a trabajar de forma más o menos independiente, pero en el cómic más minoritario estas labores se suelen concentrar en la misma persona. Como parece lógico, en el caso de los cómics autobiográficos lo habitual es que el guionista sea también el dibujante. Sin embargo, hay algunas excepciones llamativas. Por ejemplo Harvey Pekar, considerado como uno de los padres del cómic autobiográfico por su célebre American Splendor (que se viene publicando desde 1976), sólo se ocupa de escribir los guiones, y una larga lista de dibujantes, entre ellos R. Crumb, Alison Bechdel y Chester Brown, han ilustrado sus historias. También The Quitter (2005), tal vez su obra más personal, fue ilustrada por Dean Haspiel y muestra por primera vez los años de adolescencia de Pekar.

9 Mercier, J-P., «Autobiographie et bande desinée», en Lejeune Ph. (dir.), Récits de vies et médias. Ritm, 20 (1999), pp. 157-165, p. 158.
} 
amargo y crítico marcaría ya desde sus inicios el carácter de la historieta íntima estadounidense. Pero sería Robert Crumb quien, ya en la época, se alzara popularmente con el título de padre fundador del género, especialmente a partir de $M y$ Trouble with Women (1980), donde el veterano dibujante llevó a cabo un esfuerzo consciente por abordar sus problemas sexuales como un derivado de su estricta infancia católica. Desde entonces, con humorismo y buenas dosis de autoparodia, Crumb ha seguido explorando su vida en imágenes y ha ejercido una fuerte influencia sobre muchos autores jóvenes, como Joe Matt, Julie Doucet y Chester Brown. Influidas también por este movimiento, muchas mujeres del mundo del cómic underground, por ejemplo Phoebe Gloeckner (A Child's Life, 1998) y Aline Kominsky (con su obsesivo personaje The Bunch), comenzaron a explorar también las posibilidades de la historieta autobiográfica como medio de expresión personal y reivindicación subcultural feminista. Después, con los años, el tema autobiográfico iría abandonando lo exclusivamente minoritario para frecuentar otras esferas más comerciales y mayoritarias, y es de notar que en esa época incluso el mítico Will Eisner renunció a su silencio de décadas para publicar una recopilación de historias con tintes autobiográficos (A contract with God, 1978) donde aludía a la muerte de su hija Alice. Sin embargo, sería finalmente Art Spiegelman quien abriera el campo de expresión del cómic a la historia, a la reflexión humana y a la biografía en su monumental Maus: A Survivor's Tale (1980-1991). En esta obra, punto de inflexión en la historia del cómic, Art Spiegelman narra dos cursos de acción paralelos: por un lado, las peripecias reales de su padre, Vladek, de origen judíopolaco, durante la Segunda Guerra Mundial; y por otro lado, el relato en primera persona de las entrevistas del propio Art con su padre en el Nueva York de los ochenta para recoger los materiales de su cómic. El premio Pulitzer que le fue otorgado a Maus en 1992 constituye el signo patente del comienzo de una nueva era para el cómic, ahora reconocido como un arte de propio derecho.

A raíz de estos acontecimientos, la influencia de Crumb y de Spiegelman se extendió rápidamente por Europa durante la década de los noventa. Francia, que contaba ya con una larga tradición el mundo del cómic, fue el primer país que acogió este movimiento y contribuyó a difundir el tema autobiográfico. De hecho, el creciente interés de los historietistas franceses por temas adultos y más literarios derivó incluso en el surgimiento de la llamada Nouvelle Bande Desinée (el Nuevo Cómic), un movimiento independiente de finales de los noventa que rechazaba el cómic juvenil en color y pugnaba por otro con temas adultos donde primara la solidez del guión. Las obras autobiográficas L'Ascension du Haut Mal (1993-2001) de David B. y Approximativement (1995) de Lewis Trondheim constituyen, en este sentido, un referente importante para la maduración del cómic adulto francés. Por tanto, desde los noventa, al mismo tiempo que los cómics se transformaban en un producto cultural común en Europa, la autobiografía se convertía por su parte en el 
género más representativo del cómic independiente y artístico ${ }^{10}$. Así lo demuestran el éxito de Persepolis (2000), de Marjane Satrapi, y la fundación de la editorial Ego Comme X, dedicada en exclusiva al cómic autobiográfico.

En España sin embargo el interés por este tipo de producciones es todavía un fenómeno reciente. Paracuellos, con su cruda denuncia semiautobiográfica de los malos tratos que se vivían en los hogares de auxilio franquistas, se ha convertido hoy en día en ejemplo indispensable del cómic de memorias; sin embargo la obra tardó décadas en crear escuela. Las primeras entregas de lo que llegaría a ser Paracuellos tuvieron tan escaso éxito que el autor, Carlos Giménez, sólo pudo continuar su proyecto gracias al interés que despertó en el mercado francés. Así, aunque los primeros dos álbumes de la serie fueron realizados a finales de los años setenta y primeros ochenta, no sería hasta veinte años más tarde, ya a finales de los noventa, cuando Giménez concluiría su obra con otros cuatro álbumes más. Pero con el cambio de siglo sí han visto la luz un gran número de cómics autobiográficos españoles. Entre ellos destaca el trabajo de Ramón Boldú en El arte de criar malvas (2007), donde siguiendo el ejemplo canónico de Crumb plasma sus miserias sexuales y su dislocada vida sentimental, y sobre todo de Miguel Gallardo, que con un estilo limpio e infantil ha dado cuenta de la vida de su hija autista en María y yo (2007).

En conclusión, en apenas tres décadas el cómic autobiográfico ha viajado de lo independiente y underground al éxito editorial y cultural. Pero es importante señalar que este auge de lo autobiográfico y lo personal a partir de los setenta no es, desde luego, exclusivo del cómic, sino que se sitúa en un proceso cultural muy amplio relacionado con la progresiva democratización de la sociedad occidental y la creciente exigencia de libertad individual. Desde los setenta, las esferas sociales $\mathrm{y}$ artísticas han vivido un proceso democratizador gracias al cual todo ciudadano se convierte en un ser importante $y$, por ende, con derecho a contar su historia privada (a tener sus quince minutos de fama). Esta creciente importancia del individuo y de las pequeñas historias personales se refleja bien en fenómenos sociales contemporáneos como el auge de los blogs, los reality shows, los talk shows, el periodismo ciudadano, el amateurismo artístico, etc., pero también en el fuerte desarrollo de los géneros literarios autobiográficos. Desde los setenta, los libros de memorias, el diario íntimo y la correspondencia han vivido un éxito sin precedentes en el mercado editorial europeo y estadounidense; e incluso las letras españolas, con escasa tradición en lo confesional, se sumaron con fuerza al movimiento11. Este boom interna-

10 Beaty, B., Unpopular culture: transforming the European comic book in the 1990s, Toronto, University of Toronto Press, 2007, p. 12.

11 «Pues bien, muerto Franco (casi) todo el mundo se puso a escribir sus memorias. El género se puso de moda y tuvo, en consecuencia, un gran eco. Un cambio de rasante se había producido. De ahí, que lo autobiográfico germinó con una inusitada fuerza y los españoles - tan acostumbrados a perder el tren en otras épocas- se iban a subir en el de alta velocidad de la literatura íntima», Romera Castillo, J., De primera mano. Sobre escritura autobiográfica en España, Madrid, Visor, 2006, p. 23. 
cional de lo autobiográfico vino también acompañado de una de las más agrias y enriquecedoras polémicas de la teoría literaria contemporánea: la discusión posestructuralista sobre la capacidad mimética de la escritura, es decir, sobre si la realidad puede ser representada o si quiera enunciada de forma objetiva. La posibilidad de acceder a un conocimiento auténtico del pasado gracias a una investigación historiográfica, o incluso la viabilidad de plasmar de forma veraz el mundo en una novela realista, fue severamente revisada para poner de relieve el componente narrativo inherente a todo discurso ${ }^{12}$. Autores como P. De Man llegaron incluso a negar la capacidad del lenguaje para representar el mundo, alegando que el lenguaje es una metáfora que no permite aludir de forma directa a lo real13. En líneas generales, el debate sirvió principalmente para poner en evidencia que todo arte, incluso el más realista o confesional, ofrece una versión de la realidad mediada por una opinión personal, una voluntad de estilo, cierta selección y disposición de materiales, y sobre todo, por el propio sentido simbólico de los lenguajes artísticos. Esto, desde luego, no impide que un relato histórico o una crónica puedan ser honestas, pero sí que insinúa que los parecidos entre ficción y no ficción son notables. La prueba de ello es que los géneros de ficción pueden, lúdicamente, hacerse pasar por testimonios reales (como el Lazarillo, infinidad de novelas han jugado a adoptar la forma de la confesión, y hoy en día muchas películas fantásticas o de terror imitan el tono verídico del documental). Y a pesar de todo, el público no suele tener mayor problema para distinguir cuándo una obra está aludiendo a la realidad y cuándo está planteando una situación puramente imaginara (salvo en casos extremos, como la famosa retransmisión radiofónica de La guerra de los mundos). Ello se debe principalmente a que los autores de no ficción, para garantizar ante su público que están siendo fieles a los hechos que cuentan, buscan establecer con el público pactos «pragmáticos» o comunicativos mediante diversas estrategias o recursos narrativos: prefacios, firmas, el uso de sus nombres propios, acumulación de datos, fechas, etcétera ${ }^{14}$.

Así pues, en las siguientes páginas, se analizarán las características del lenguaje de los cómics autobiográficos, haciendo especial hincapié en los recursos narrativos destinados a probar la fidelidad del relato con respecto a los hechos. Con el objetivo de seleccionar y distribuir los parámetros de estudio de forma coherente, se par-

\footnotetext{
12 Barthes, R., «Le discours de 1'histoire», Social Science Information / Information sur les sciences sociales, 6 (1967), pp. 65-75.

13 La polémica se resume bien en el comentadísimo texto de De Man P., «Autobiography as De-facement», MLN, 94. 5 (1979), pp. 919-930. Muchos autores respondieron luego a estas posiciones extremas defendiendo la viabilidad de la autobiografía, véase sobre todo Loureiro, Á., The ethics of autobiography: replacing the subject in modern Spain, Nashville, Vanderbilt University Press, 2000, especialmente «Before Reference», pp. 1-30.

14 El concepto de «pacto autobiográfico» se tomará aquí como fue concebido originalmente por Lejeune P., Le pacte autobiographique, París, Seuil, 1975.
} 
tirá de las características externas del cómic para ahondar progresivamente en sus significados más internos. Así, tomando primero las características externas del libro cómic (portada, subtítulos), se irá profundizando en el estilo de las viñetas que lo conforman, la estructura en que se disponen y finalmente el contenido que abordan.

Puede parecer extraño comenzar este análisis partiendo del cómic como objeto físico, de sus portadas, títulos y subtítulos, pero estos elementos «paratextuales» 15 ocupan un lugar importante en los géneros de no ficción. Al conformar un umbral imprescindible para el relato, contribuyen a plasmar la idea de que el autor se responsabiliza de su narración no ficticia antes incluso de que se acceda a la lectura del texto 16 .

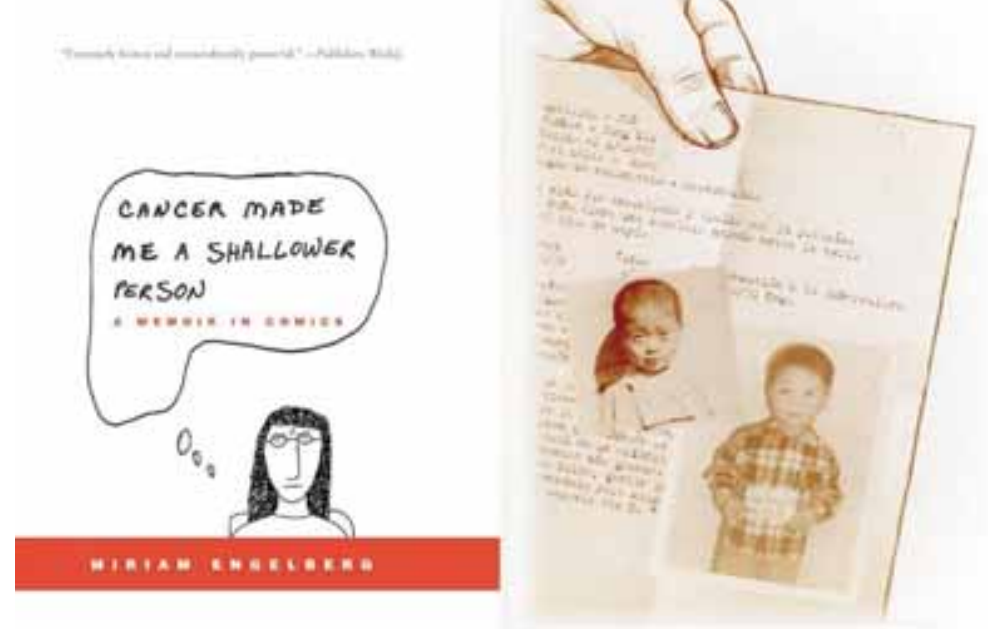

Désœuvré, de Lewis Trondheim (2005), es sin duda un cómic poco común, pero su subtítulo «Ensayo», guía desde el principio las expectativas del lector. A lo largo de sus páginas, Trondheim, encarnado en su bien conocido álter ego animal, elabora una densa reflexión personal sobre el declive de toda una generación de autores de cómic, abatidos en su creatividad por un éxito inesperado. Miriam Engelberg, autora de Cancer Made Me a Shallower Person: A Memoir in Comics (2006), además de retratarse en la portada de su libro, incluye una introducción acerca de las razones que la llevaron a elegir el cómic como medio de plasmar su experiencia de enferma de cáncer. Alison Bechdel, autora de Fun Home: A Family Tragicomic (2006), acude habitualmente al dibujo de fotografías familiares e incluye una en la

15 Se parte aquí de la noción elaborada por Genette, G. (Seuils, París, Seuil, 1987), según la cual la existencia del paratexto determina que un texto se convierta en libro, es decir, en producto destinado a la recepción y venta pública. En este sentido, Genette opera una subdivisión entre el peritexto, que abarcaría las secuencias paratextuales del interior del libro (títulos, prefacios, notas a pie de página), y el epitexto, que aparecería fuera del libro (entrevistas a los autores, reseñas, diarios y correspondencia). Aquí, por motivos de espacio, sólo se tomará en cuenta el primer subgrupo.

16 Imágenes: Engelberg, M., Cancer made me a shallower person, Nueva York, Harper Paperbacks, 2006; Sik Jun, J., Color de piel: miel, Gerona, Rossell Fantasy Work, 2008. 
propia cubierta. Pero el caso más llamativo puede ser el de Jung Sik Jun en Couleur de peau: miel (2007), libro que detalla su infancia de niño coreano adoptado por una familia belga, y en el que llega a incluir una transcripción de su ficha de adopción en la tercera de cubierta, así como un postfacio donde comenta algunos pormenores del proceso de creación de su libro. Esta combinación de imágenes en la cubierta, títulos, subtítulos, prefacios y postfacios, tan característica de las producciones autobiográficas, busca potenciar la identificación entre el autor y el personaje protagonista del relato. Una unión ya de por sí notable en el cómic dado que comúnmente el guionista de un cómic autobiográfico ejerce también de dibujante, y esa fusión de testimonio y autorretrato añade más contenido personal a la obra. De alguna manera, esa efigie funciona como una firma manuscrita mediante la que el autor sella su relato al mismo tiempo que muestra, con una sola imagen, cómo se visualiza a sí mismo.

Pero más allá de estos atributos de género, presentes también a su manera en las manifestaciones no ficticias de otras artes, el cómic autobiográfico se caracteriza sobre todo por sus rasgos narrativos estilísticos y estructurales. Para entender cómo funciona la narrativa del cómic conviene tener en cuenta que su alcance está determinado por su naturaleza híbrida entre lenguaje e ilustración. Tanto palabras como imágenes son iconos que señalan aspectos del mundo real, pero las palabras tienen una naturaleza puramente abstracta y su representación gráfica no afecta al contenido ya que no guardan relación con lo que representan. Sin embargo, en el caso de los dibujos, que están hechos para parecerse a su referente, su apariencia y formato (más o menos icónicos, más o menos realistas) sí afecta a su significado. Por ello, es posible decir que estos iconos tienen un contenido aspectual, pues su apariencia (cómo han sido dibujados) influye en su significado. Un nivel mayor o menor de abstracción, un nivel de detalle o realismo superior, un trazo oscuro o limpio, el uso de color... determinará la recepción estética por parte del espectador. En consecuencia, todo cómic ilustrado, incluso el de trazo más realista, se caracteriza por ofrecer una representación abstracta de la realidad. Esta iconización del mundo y de los rostros de los personajes permite que el significado de esos dibujos se haga también abstracto, es decir, que aumente su capacidad para hacer referencia a cualquier persona o situación. En otras palabras, cuanto más sencillos o icónicos sean los rasgos del dibujo de un personaje, más difícil será otorgarle una personalidad distintiva, separada de la de otros personajes, pero más fácil resultará que el lector pueda ponerse en su lugar, reflejarse en él17.

En este sentido, cabe detenerse un momento a comparar el alcance simbólico de la fotografía y el cómic. El retrato fotográfico puede despertar sentimientos de horror o compasión en el espectador al concretar un conflicto anónimo en los ras-

17 McCloud 2007, op. cit. (nota 1), p. 36. 
gos individuales de un rostro (como la famosa foto de Nick Ut de la niña vietnamita que huye desnuda o el retrato de la afgana Sharbat Gula para el National Geographic). Pero la abstracción del cómic favorece un efecto de generalización mediante el que cada rostro esbozado renuncia a su individualidad para adquirir un significado simbólico global. En otras palabras, una fotografía concreta un desastre global en una historia individual; por el contrario, la iconización del cómic incita a asumir la tragedia privada de los personajes como un asunto universal. Como demuestran los dibujos casi infantiles de Persépolis, un estilo sencillo puede albergar un significado extremadamente complejo ${ }^{18}$.

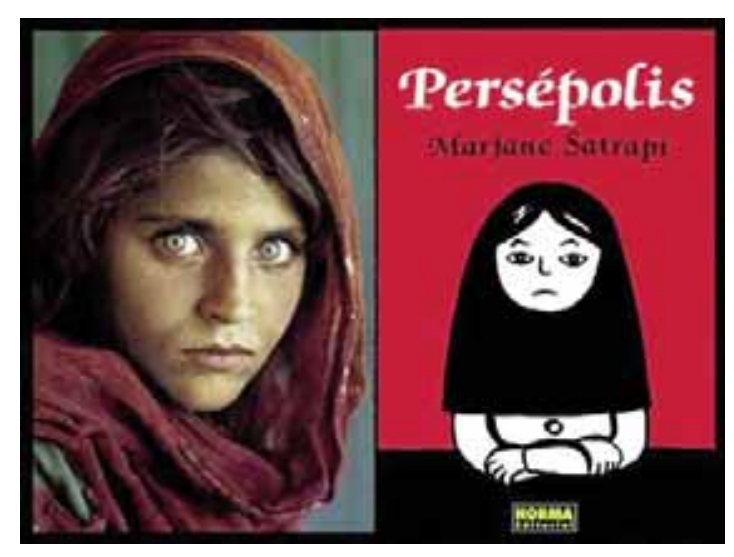

En este poder de abstracción y capacidad empática de los iconos radica la razón de que tantos dibujantes utilicen líneas muy simples para sus dibujos, especialmente para los rostros de los personajes, aunque luego el escenario sea rico en detalles (efecto «máscara» según McCloud ${ }^{19}$ ). En Paracuellos, por ejemplo, es fácil observar que Giménez utiliza un estilo extremadamente sencillo para dibujar las caras de los niños del hogar mientras que sus temibles cuidadores son retratados con un detalle llamativo; esta técnica permite que el lector pueda ponerse en el lugar de las víctimas y sentir más alejamiento de los maltratadores.

Sin embargo, es obvio que la representación abstracta inherente a las ilustraciones del cómic, aunque permite que el contenido semántico del dibujo alcance un sentido más universal, también conlleva cierta pérdida de objetividad y especificidad. ¿Cómo combinar entonces abstracción y testimonio? En general, los autores de autobiografías mínimas y personales - menos interesados en probar la fiabilidad de sus relatos que en ofrecer una imagen directa y espontánea de sus vivencias cotidianas-asumen la abstracción inherente al cómic de forma positiva. Así por ejemplo, el mencionado María y yo, de Miguel Gallardo, o Little Things: A Memoir in Slices, el primer cómic autobiográfico no underground de Jeffrey Brown (2008), se carac-

18 Imágenes: McCurry S., «Afghan girl», National Geographic, vol. 176, n. 6 (junio 1984); Satrapi, M., Persépolis, Barcelona, Norma, 2007.

19 McCloud 2007, op. cit. (nota 1), pp. 51-52. 
terizan por un estilo de apariencia primitivo y descuidado. Mediante esta técnica de trazo elemental los autores pretenden potenciar la sensación de espontaneidad de su historia, favorecer la impresión de que los dibujos fueron abocetados en el calor del momento y nunca retocados después. Incluso cómics como Persépolis de Satrapi y Pyongyan de Guy Delisle no enfocan su respectiva denuncia de los regímenes iraní y norcoreano desde un punto de vista histórico o ensayístico, sino que prefieren usar el lenguaje del cómic para contar sus pequeñas aventuras personales con un estilo de ilustración extremadamente sencillo, de modo que el lector pueda extraer a partir de ahí conclusiones más generales. En el extremo opuesto, el periodista Joe Sacco (famoso por sus cómics entre la crónica y lo autobiográfico) sí está interesado en mostrar su adhesión a los hechos tal cual sucedieron, por lo que asume un estilo de dibujo más realista o cercano a lo fotográfico. Sus narraciones utilizan por tanto un estilo detallado, oscuro, casi feísta. Mediante esta técnica, Sacco trata de potenciar la objetividad de su narración, mostrar que no oculta ningún aspecto de la realidad que está documentando. En todo caso, entre realismo y abstracción pura, hay también estilos intermedios muy interesantes, como Paracuellos, Fun Home, Blankets y, sobre todo, Maus. Este último cómic, cumbre de la experimentación con una técnica híbrida de dibujo, se caracteriza por combinar un estilo realista en los decorados con otro icónico para los rostros de los personajes, los cuales quedan uniformizados en una metáfora animal: los judíos son ratones, los alemanes gatos, los polacos cerdos, los americanos perros, etc. Esta combinación de realismo y abstracción busca la verosimilitud al mismo tiempo que despoja de rasgos individuales el rostro particular de las víctimas del Holocausto. Así, la figura icónica de los protagonistas se convierte en símbolo de todos los judíos, y el lector puede ponerse tras esos rostros y asumir su historia como si fuera propia. Además, el uso del blanco y negro en toda la narración -un recurso habitual del cómic autobiográfico tanto por motivos editoriales como artísticos- potencia la fuerza subjetiva de estos acercamientos simbólicos a la realidad.

A estos rasgos estilísticos del cómic autobiográfico se unen, por supuesto, otros recursos formales de orden textual. De hecho, este tipo de historieta suele caracterizarse por poner en juego un estilo de redacción donde la palabra cobra una gran importancia (no es casualidad que el auge del cómic autobiográfico se relacione desde los setenta con la reivindicación de un cómic más literario). Los pasajes reflexivos, líricos o cruelmente autoparódicos abundan, tanto en boca de los personajes como sobre todo del narrador. Así, no es sólo que los monólogos o diálogos entre personajes sean habituales y extensos, sino que la figura del narrador, que se expresa desde los cartuchos de texto, tiende a cobrar una importancia inusitada. Del mismo modo que la autobiografía literaria suele estar dominada por la voz del narrador, que desde el presente reflexiona sobre su pasado hasta el punto de que el personaje puede no llegar a expresarse directamente nunca, el cómic de no fícción 
recurre también a una voz narradora que va desgranando el relato y dirigiendo la acción. En Palestine, de Joe Sacco, la presencia del narrador es continua desde muchos cartuchos y comentarios externos insertos en numerosas viñetas. Esa voz ajena, hilo conductor de las historias que va presenciando, asegura un cauce donde la subjetividad de la primera persona parece diluirse; pues mientras los bocadillos ponen en boca de los personajes su testimonio directo, la caja de texto parece transmitir los pensamientos de una voz omnipresente y por lo tanto más objetiva20:

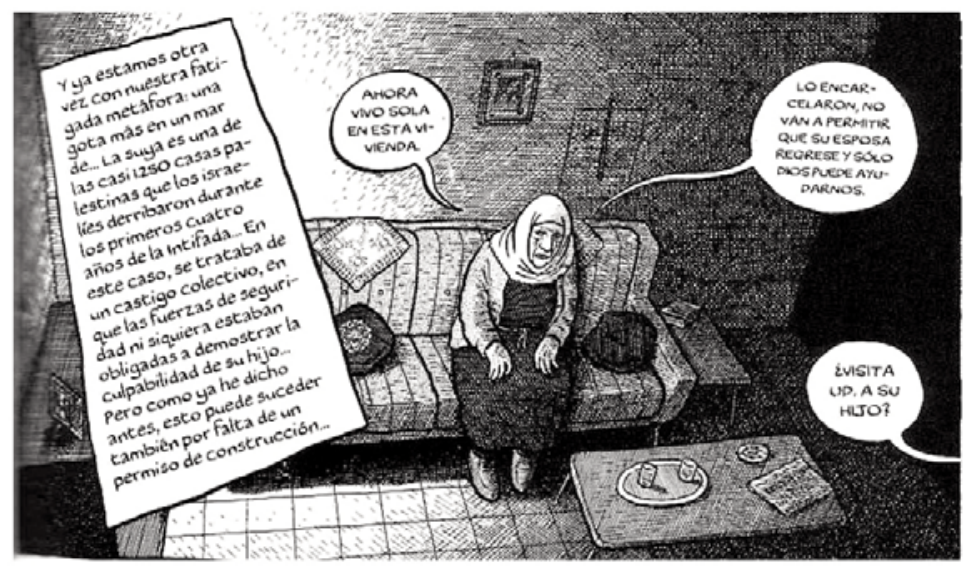

La combinación de estrategias de ilustración y textuales antes señalada opera en el cómic autobiográfico propiciando una lectura particular. Tradicionalmente, en el cómic se recurre a un estilo de dibujo más bien sencillo y a un lenguaje directo que permita captar rápidamente imágenes y palabras, integrándolas en un todo armonioso. Pero cuando el estilo del discurso escrito alcanza una complejidad sintáctica y estilística importante, o si el dibujo gana en dificultad o tiende hacia el expresionismo, el lector debe tomarse su tiempo para captar los detalles e imponerse así un ritmo de lectura pausado y reflexivo.

Del mismo modo, si las viñetas conforman las unidades semánticas del cómic, su disposición estructural (o «clausura») determina la gramática de la narración. En este sentido, la complejidad de las relaciones entre viñetas influirá poderosamente en el efecto que se produce sobre los lectores. En otras palabras, la disposición de las viñetas, sus relaciones con las cajas de texto, su tamaño, su ordenamiento en el sentido clásico de lectura (de izquierda a derecha, de arriba abajo) u en otro orden, el grosor de las líneas que enmarcan habitualmente las imágenes o su ausencia, la relación temporal entre cada viñeta (si narran el argumento escena a escena, acción a acción, con elipsis, etc.) son parámetros que determinarán la estructura del cómic.

En este sentido, explicando por qué Paracuellos está narrado con una estructura inmóvil de rígidas y pequeñas viñetas, Carlos Giménez comenta:

20 Sacco, J., Palestina, Madrid, Planeta-DeAgostini, 2002, p. 69. 
Por varias razones. Primero porque es una historia que necesita muy pocos decorados, una vez que has dicho «Eso es un colegio», pues es un colegio. Segundo, las grandes viñetas permiten decorados bonitos, yo aquí no tenía ningún interés en que me quedasen decorados bonitos, porque aunque lo que dibujes sea feo, el hecho de dibujarlo en grande, y si te sale bien todavía peor, queda bonito. Los decorados mínimos, las dos rayitas, la puertita, para que nadie pueda decir «Uy, qué bonito», porque ese colegio no era bonito, era feo, y la sensación que tienes que dar es que en ese colegio no se pasa bien y no se vive bien. Y luego el papel es la cárcel más inmediata del autor de tebeos. En la medida en la que yo hiciera viñetas pequeñitas podía contar más cosas y podía contarlas de forma más matizada 21 .

Las limitaciones que inevitablemente impone el papel se plasman en la retícula que encauza la narración. No se trata sólo del hecho evidente de que las viñetas amplias o impresas a sangre (como numerosas páginas de Blankets), así como los planos medios o generales (como en María y yo) ofrezcan una sensación de desahogo opuesta a la estrechez de las diminutas y estrictas casillas de Paracuellos, cuyos primeros planos continuos incrementan la intensidad de las emociones. La importancia de la estructura de las viñetas radica sobre todo, como apunta Giménez, en que cada estructura permite tejer un ritmo de narración con matices diferentes. En el caso de Paracuellos, pero también de Maus, Palestine o Persépolis, donde se persigue ofrecer una historia detallada e informativa, la estructura de narración es rígida, avanza deprisa y sólo se permite variar su minucioso ritmo con viñetas amplias o de formas peculiares en momentos de especial intensidad emocional. En cambio, las narraciones centradas en el lirismo de su historia, cuyo propósito no es tanto informativo como de mera recreación personal, se atienen con menos firmeza a las estructuras tradicionales de la disposición en viñetas, e incluso carecen de ellas (acercándose así a la libertad expositiva del libro de dibujos). En este sentido, Blankets, Color de peau: miel o María y yo, entre muchos otros, ofrecen disposiciones caprichosas entre viñetas, con órdenes de lectura inusuales, numerosas páginas con una sola imagen y una fuerte presencia de texto narrativo o dialógico encajado dentro del dibujo.

De hecho, este ritmo acelerado o pausado, informativo o expositivo que pueda adquirir un cómic también se conjuga con la disposición de la voz narradora. Como bien ejemplifica la imagen de Paracuellos incluida a continuación, el uso de bocadillos de diálogo hace que la acción fluya, mientras que las viñetas sin diálogo o con un mero cartucho de texto congelan la imagen y la vuelve más estática (manifestándose así de nuevo el componente atemporal y objetivo de la voz del narrador) ${ }^{22}$.

\footnotetext{
21 Entrevista por Muñoz D. y Trashorras A., «Carlos Giménez», U, el hijo de Urich, 9 (1998), pp. 2063. Cursiva propia.

22 Giménez, C., «Canción de Navidad», Paracuellos, vol. 1, Barcelona, Glénat, 2000, p. 10.
} 


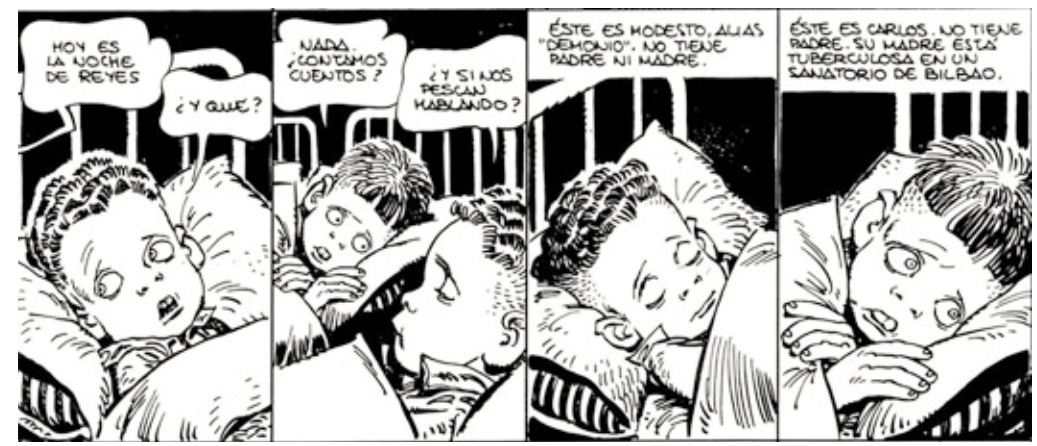

Esta voz narradora (omnisciente e impersonal en el caso de Paracuellos, enfocada desde la primera persona y por lo tanto más subjetiva en la mayoría de cómics autobiográficos) encauza el relato retrospectivo de las peripecias del personaje. Y aunque normalmente la historia del narrador sigue una disposición diacrónica, hay casos en que la estructura temporal del relato se quiebra para adoptar una forma más compleja. Es común encontrar flash backs, flash forwards y elipsis encajadas dentro de la narración. Pero además, puede acudirse a recursos más complejos, como la disposición en forma de «muñecas rusas» o «cajas chinas», donde una historia engloba a otra. Mediante esta técnica de relato se permite que convivan dos planos temporales: uno actual en el que el narrador-protagonista desarrolla ciertos recuerdos, y otro pasado donde actúan los personajes de la historia recordada. Así ocurre por ejemplo en Maus, en Hate de Peter Bagge (1990) y en Violent Cases (1987), un cómic pseudoautobiográfico firmado por Neil Gaiman (y dibujado por David McKean) que juega con algunos difuminados recuerdos de la infancia del guionista23:

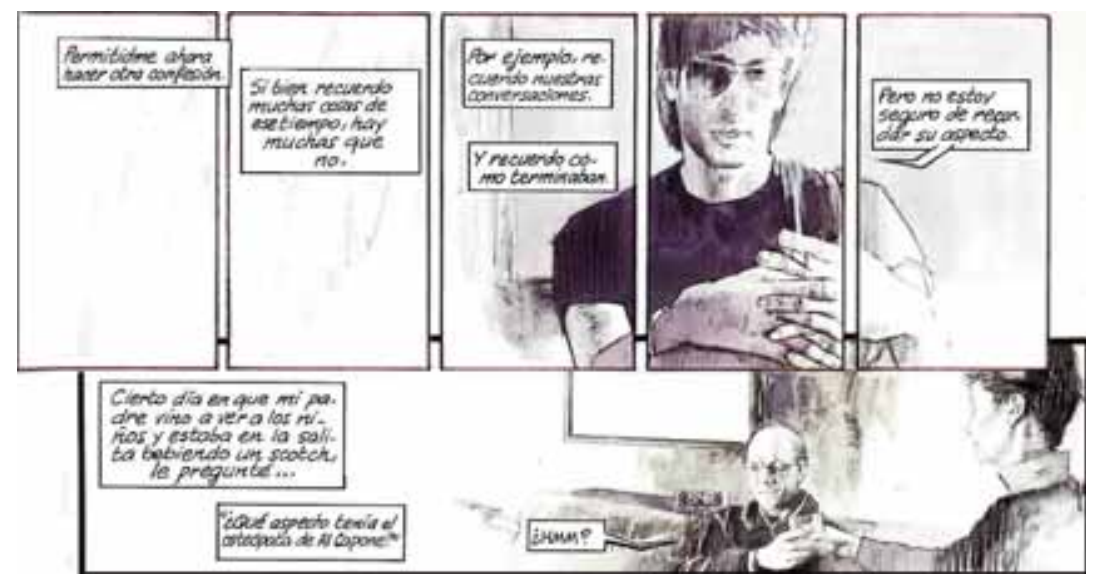

En el primer nivel de acción un narrador identificado como Gaiman bucea en su pasado hasta llegar a otro lejano momento temporal, unos breves días de su infancia donde descubrió el significado de la magia y la violencia. Este recurso organizativo ofrece la ventaja de que el autor no sólo se retrata a sí mismo como personaje, con su aspecto infantil, sino también como narrador, y por lo tanto con su aspec-

23 Gaiman, N. y McKean, D., Casos violentos, Barcelona, Zinco, 1993, p. 8. 
to adulto. La doble presencia del guionista contribuye a que la narración gane en verosimilitud, pues permite al autor intervenir en el proceso de estructuración de su historia y negociar directamente con el lector un pacto de confianza. En este sentido, resulta notable cómo Violent Cases logra mantener su apariencia autobiográfica a pesar de que el narrador confiese varias veces que sus recuerdos vienen de un pasado difuso e incierto. La encarnación de Gaiman como narrador y su tono confidencial potenciado por el uso de la primera persona otorga al cómic un halo de sinceridad tan poderoso que incluso permite al lector pasar por alto las confesadas manipulaciones de la memoria y los tintes mágicos del argumento.

Este ejemplo resulta, de hecho, idóneo para señalar también las implicaciones del último aspecto del cómic autobiográfico que aquí se analizará: su temática. Como resulta habitual en toda narración memorística, el cómic autobiográfico tiende a desarrollar una historia retrospectiva en que el narrador-personaje recorre algún periodo largo de su vida (infancia y juventud especialmente) o momentos puntuales muy significativos (una enfermedad, un viaje crucial, un encuentro perturbador, el primer amor). Buena parte de las confesiones que acogen estos cómics alcanzan una intensidad dramática inusitada, sobre todo en un arte tradicionalmente asociado con las aventuras y el público adolescente. Por ejemplo, Prisoner of the Hell Planet (1972) aborda el crudo suicidio de la madre de Art Spiegelman, y Papa (2006) el suicidio del padre de la francesa Aude Picault. Pilules Bleues (2001) relata las relaciones de Frederik Peeters con una mujer seropositiva, e incluye además un detallado cuadro de su complicada vida sexual. Fun Home, por su parte, expone sin tapujos el angustioso proceso de Alice Bechel para asumir su propia homosexualidad así como la homosexualidad encubierta de su padre.

Ahora bien, estos procesos de tormentosa confesión no siempre son puramente documentales, sino que también pueden convivir con incursiones en lo onírico, lo esquizofrénico o lo imaginario (como las charlas nocturnas de Marjane Satrapi con Dios). Por lo general estos desvíos argumentales hacia lo surreal buscan sólo incrementar la intensidad dramática del cómic sin llegar a restar verosimilitud a la narración biográfica. Pero hay casos donde este límite se difumina. Así, por ejemplo, en la serie Monstrueux (1999-2001), Trondheim ofrece una versión de su propia familia vista a través de los ojos de sus hijos, creando así un universo alocado donde lo real se mezcla de continuo con la imaginación, y la inocencia con el sadismo infantil. Un paso más allá en el camino hacia la ficción se encuentra Lupus (2003-2006), una historia casi costumbrista de Frederik Peeters ambientada sin embargo en un universo de ciencia-ficción. El propio autor ha reconocido a este respecto: «Lupus es autoficción. No hay hechos objetivos. Simplemente introduje emociones de la infancia, recuerdos de algunos viajes... Pero yo no soy el protagonista» 24 , dejándo-

24 Braun, A., «Cómo cocinar una ratatouille», El País. Babelia (13 de septiembre de 2008), p. 12. 
nos así intuir que los vínculos personales del autor con su obra no siempre se ciñen a los géneros tradicionales sino que pueden transitar por el vastísimo espacio intermedio que se abre entre la autobiografía estricta y la ficción pura.

En todo caso, sin llegar a estos extremos y ciñéndose a los hechos, el autor de cómic tiene también la posibilidad de plantear una representación explícita y objetiva del contenido o acudir a un estilo expresionista y subjetivo. Como se mencionó antes, dada la capacidad de abstracción inherente al cómic, el autor puede decantarse por un estilo icónico que fomente la empatía lectora o por otro realista que promueva la verosimilitud. Pero también existe una vía estilística que transita el expresionismo y que sirve para poner de relieve el punto de vista subjetivo desde el que se relata el argumento de la historia. En Blankets, Craigh Thompson emplea este recurso en numerosas ocasiones para retratar a su amor de adolescencia, Raina. Haciendo un esfuerzo por recuperar los sentimientos de su yo pasado, el autor acude al expresionismo para pintar no tanto un retrato objetivo de Raina como una visión tamizada por la subjetividad del adolescente enamorado. Su amada aparece encarnada en ángel o en sacerdotisa, retratada una y otra vez en la misma página con fantasioso capricho. Algo similar sucede también en el cómic de David B. L'Ascension du Haut Mal (1993-2006), sobre los problemas familiares que conllevó la epilepsia de su hermano. El cómic cuenta una historia verídica, pero no duda en forzar el realismo de la representación de los sucesos para favorecer un relato encauzado desde la subjetividad del autor, lo cual se refleja en el agresivo entintado blanco y negro, los claroscuros expresionistas y la deformación frecuente de las figuras y situaciones 25 .

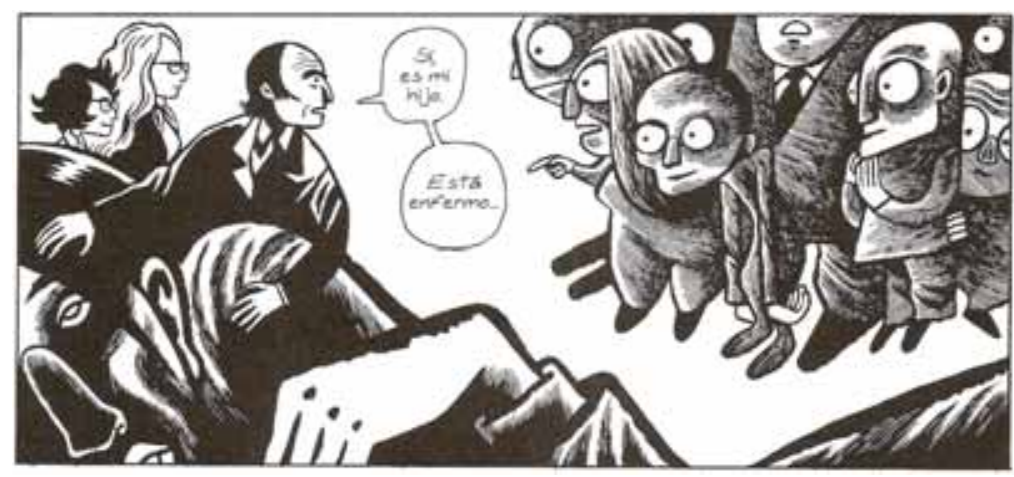

\section{Alcance cultural del cómic autobiográfico}

Todas las características estilísticas, estructurales y temáticas del cómic autobiográfico analizadas hasta aquí representan avances formales hacia la configuración de un modelo de historieta memorialística maduro y consolidado. El esfuerzo

25 David B., Epiléptico: La ascensión del gran mal, Madrid, Sinsentido, 2009, p. 19. 
llevado a cabo desde los setenta por guionistas y dibujantes para adaptar el lenguaje del cómic a unas nuevas necesidades de expresión artística y personal supuso un paso definitivo en su camino hacia el reconocimiento. Pero el hecho de que tantos autores se interesaran en apenas unas décadas por desarrollar historias ligadas a la expresión de su situación personal no es desde luego casual. La tendencia autobiográfica alcanzó a veteranos como Will Eisner o Jean Giraud, alias Moebius ( $\mathrm{La}$ déviation. Pilote, 1973) hasta recién llegados al mundillo como Edmond Badouin, quien sin contar apenas con formación en el cómic se interesó desde el principio por las historias íntimas (Passe le temps 1982). Este súbito impulso creativo que recorrió el cómic estadounidense y europeo -y japonés, en una pequeña pero significativa medida- no podría explicarse sin tener en cuenta el contexto cultural de la última mitad del siglo XX, y sin correlacionarlo con el cambio simultáneo en la mentalidad del público occidental, cada vez más ávido de formas originales, sinceras y directas de expresión personal.

En efecto, el desarrollo del cómic autobiográfico y su progresiva instalación en el canon artístico desde principios de los setenta coincide cronológicamente con la tendencia generalizada en otros medios artísticos a rechazar los tradicionales metarrelatos ideológicos y tomar los discursos privados como cauce privilegiado de expresión. Lipovetsky 26 ha descrito largamente cómo, desde la Segunda Guerra Mundial, la sociedad occidental emprendió un viraje hacia la despolitización y el desmantelamiento de las grandes estructuras de pensamiento (socialismo, comunismo, fascismo, religiones institucionalizadas) para asumir formas ideológicas más individuales. De forma simultánea, el arte siguió los mismos caminos. Desde los años setenta, en concreto, se hizo aún más patente en todos los ámbitos culturales este abandono progresivo de los sistemas ideológicos justificativos a favor de un culto a la liberación personal, la microhistoria, los intereses individuales, los grupos artísticos cada vez más minoritarios y el derecho de todo el mundo a contar su historia personal y diferenciadora. Según Lipovetsky, en el avance cultural de Occidente durante las últimas décadas, la libertad individual ha adquirido una relevancia absoluta, lo que explica que las manifestaciones artísticas hayan perdido su antiguo enfoque social para centrarse de forma preferente en el individuo. En una sociedad democrática en la que todo ciudadano es importante y donde los derechos de cualquiera deben ser respetados, hasta la circunstancia autobiográfica más anodina merece ser contada; una «obsesión moderna del Yo en su deseo de revelar su ser auténtico», según Lipovetsky27. En este contexto, la evolución cómic hacia una

\footnotetext{
26 Lipovetsky, G., La era del vacio, Barcelona, Anagrama, 1986, sobre todo el capítulo III, pp. 49-78. Sobre el mismo asunto véase también Vattimo, G., El fin de la modernidad, nihilismo y hermeneútica en la cultura posmoderna, Barcelona, Gedisa, 1985; Lyotard, J-F., La condición posmoderna, Madrid, Cátedra, 1989.

27 Lipovetsky 1986, op. cit. (nota 26), p. 64.
} 
forma de expresión directa, visual y rápida de los sentimientos personales ofrece otro buen ejemplo del cambio en el paradigma cultural contemporáneo. La crisis de los grandes relatos, de la Verdad con mayúscula, objetiva y accesible para todos, ha redundado en la multiplicación de muchas verdades con minúscula: formas más humildes de contar los hechos desde un punto de vista personal. Los grandes relatos históricos pierden fuerza frente a las sencillas confesiones de Crumb, David B., Trondheim, Thompson o Peeters. Incluso Spiegelman, Satrapi, Delisle o Sacco, cuyas obras se esfuerzan por denunciar la realidad histórica, acuden a pequeños relatos personales de los que ellos mismos pueden dar fe.

Por supuesto, este subjetivismo no implica que se esté negando la posibilidad de contar una historia sincera. Al contrario, por más que el cómic autobiográfico parta de cierta sospecha sobre nuestra incapacidad para conocer los hechos e interpretarlos de forma objetiva, sigue buscando la veracidad. Así expresa Joe Sacco esta paradójica (sólo en apariencia) renuncia a la objetividad y compromiso sincero con la honestidad:

Como siempre, me dibujo en mis planchas. Los lectores entienden así que lo que ven es mi punto de vista personal. Estudié periodismo, pero creo que la objetividad es una ilusión. Cuando preparamos un reportaje seleccionamos el material. No soy objetivo, pero sí trato de ser honesto. Por eso entro en la escena, es mi manera de aclarar que soy filtro y lupa de la historia [...] Hago decenas de entrevistas, como cualquier periodista. Sin embargo, lo que necesito son sugestiones visuales, así que a veces planteo a mis fuentes preguntas muy raras, del tipo: «¿Cómo ibas vestido?». No paro de tomar fotos de los mismos detalles: un coche, una casa; a la hora de representarlo no quiero inventar nada $^{28}$.

Así es como el ansia de objetividad deja paso en el cómic autobiográfico de las últimas décadas a la búsqueda de la más sincera autenticidad, a la pura honestidad. No se renuncia a contar la verdad, sólo se buscan nuevas formas más adaptadas a la sensibilidad actual para hacerlo.

Esta relación entre el desarrollo exitoso de cierto tipo de cómic y la evolución de valores culturales posmodernos resulta aún más evidente si se compara el desarrollo de la tradición historietística occidental con la japonesa. Las escuelas estadounidense y francobelga (las más potentes en Occidente) han seguido caminos bastante similares en sus valores fundamentales, pero la tradición japonesa no muestra la misma fascinación por los valores estéticos posmodernos. El mercado del cómic japonés, a pesar de ser mucho más grande y productivo que el occidental, de abarcar todos los temas posibles, incluida la vida cotidiana, de dirigirse a todas las capas de la población nacional japonesa y de contar con un respaldo gene-

${ }_{28}$ Entrevista de Magi L., «No soy objetivo, pero sí honesto», El País (25 de octubre de 2009), p. 38. 
ralizado por parte de la opinión pública, apenas ha frecuentado lo confesional o lo autobiográfico. El individualismo liberal tan arraigado en Occidente tiene allí una relevancia menor. Por supuesto, el desarrollo mediático, la globalización y la movilidad de los artistas ha propiciado un intercambio de ideas entre el cómic oriental y occidental que sólo podrá acrecentarse con el tiempo. De hecho, durante los sesenta, Yoshihiro Tatsumi 29 ya creó el formato gekiga para reivindicar un cómic más realista y comprometido, y algunos autores como Keiko Suenobu han arrasado con historias truculentas sobre las penurias sociales de los adolescentes japoneses. Pero, a pesar de las excepciones, en el masivo mercado japonés sigue primando un estilo espectacular, de estética icónica y arquetípica, bastante alejado del gusto occidental por lo personal.

\section{Conclusiones}

La inclusión de un nuevo nombre en la exclusiva lista de las artes es un evento poco común, aunque desde el último siglo ha tenido lugar una notable apertura del panorama: en su momento el cine y la fotografía, hoy el cómic, y pronto los videojuegos. Esta proliferación de manifestaciones diversas pero consideradas todas como artísticas está relacionada con el avance técnico y mediático reciente, pero también con la evolución del ideario cultural en las sociedades occidentales. En este sentido, el ejemplo del cómic permite comprobar que, para completar el viaje desde la marginalidad hacia el centro del canon, no ha sido sólo necesaria una maduración de las técnicas y temas de ese nuevo arte en ciernes, sino también una apertura en el contexto cultural del público que lo ha recibido y valorado.

Como se ha mostrado a lo largo de estas páginas, desde la mitad del siglo pasado el cómic ha perfeccionado enormemente sus técnicas, $\mathrm{y}$ ha añadido a su repertorio típico de historias juveniles, aventureros y superhéroes nuevos temas adultos tratados con un estilo literario. En concreto, resulta notable la prolífica relación que el cómic ha establecido con los relatos de temática íntima y biográfica desde los años setenta. Una relación basada ante todo en la óptima adecuación de las técnicas narrativas del cómic a la temática autobiográfica. En efecto, gracias a su naturaleza híbrida, el cómic permite que el autor se confiese en sus viñetas con una intensidad inusitada, ya que a las confidencias sobre su devenir se une un autorretrato subjetivo. Además, la capacidad de «iconización» que muestra el cómic para simplificar su estilo hasta el punto de que todo lector pueda ponerse en la piel de los personajes colabora a que la lectura de esas memorias sea un proceso igualmente intenso para el lector. Pero todas estas características intrínsecas al cómic tal vez no fueran

${ }^{29}$ La autobiografía de Tatsumi ha sido publicada recientemente en español: Una vida errante, Bilbao, Astiberri, 2009. 
suficientes para explicar el veloz auge de este arte si no se tomara en cuenta, además, su adecuación a las concepciones culturales fragmentarias e individualistas que se han desarrollado en Occidente desde los setenta. En otras palabras, en el panorama cultural de la posmodernidad, donde el Yo se revela como valor predominante, todo ciudadano ha adquirido derecho a explorar su individualidad en una narración biográfica y mostrarla públicamente. El auge del cómic se asocia por tanto con unos mecanismos narrativos que permiten saciar el deseo del público de un acceso visual directo e inmediato a las vidas ajenas. En este sentido, el cómic ha contribuido decisivamente a convertir el enfoque del hombre privado en el único punto de acceso veraz a la Historia; pues muchos testigos pueden contar los eventos acaecidos en la Segunda Guerra Mundial o en Palestina, pero sólo la auto/biografía permite hacerlo desde el punto de vista único e irrepetible del testigo. Los cómics que narran hechos históricos desde esta focalización individual no persiguen ofrecer un relato global acerca de todo lo sucedido, sino sólo una versión limitada pero estrictamente sincera sobre los hechos.

El éxito de los cómics autobiográficos en Occidente está, por lo tanto, inextricablemente unido a los cambios intelectuales que han consagrado la autenticidad personal como valor predominante en todas las esferas de la vida cultural. Y sin embargo, el veloz viaje del cómic hacia el reconocimiento crítico y social todavía no ha culminado, pues sin duda este joven arte tiene aún muchas posibilidades que explotar. 